\title{
"Ceria"
}

Jurnal Program Studi Pendidikan Anak Usia Dini

ISSN 2301-9905

Volume 7, No. 2, Januari 2018

Fakultas Keguruan dan Ilmu Pendidikan - Universitas Muhammadiyah Tangerang

\section{Upaya Meningkatkan Kemampuan Berhitung Permulaan Melalui Media Puzzle Pada Anak Usia 5-6 Tahun Di TK Permata Asri Serpong Kota Tangerang Selatan}

\author{
${ }^{1}$ Suarsih, ${ }^{2}$ Ratna Istiarini \\ 1,2Program Studi Pendidikan Guru Pendidikan Anak Usia Dini; Fakultas \\ Keguruan Dan Ilmu Pendidikan; Universitas Muhammadiyah Tangerang \\ Email : ${ }^{1}$ suarsih29@gmail.com, ${ }^{2}$ achmadapriya30@gmail.com
}

\begin{abstract}
Abstrak
Penelitian ini bertujuan untuk mengetahui kemampuan berhitung permulaan melalui media puzzle pada anak didik kelompok B TK Permata Asri Serpong Kota Tangerang Selatan. Metode yang digunakan adalah penelitian tindakan kelas yang dilakukan sebanyak tiga (3) siklus. Prosedur penelitian ini terdiri dari 4 tahap yaitu perencanaan tindakan, pelaksanaan tindakan, observasi dan refleksi. Metode pengumpulan data yang digunakan dalam penelitian ini adalah metode observasi, wawancara dan dokumentasi. Subjek penelitian ini adalah anak didik kelompok B anak yang mengalami masalah kemampuan berhitung permulaan, seperti mengenal konsep bilangan, membedakan lambang bilangan, dan dalam menulis lambang bilangan. Hasil penelitian menunjukan bahwa terjadi peningkatan kemampuan berhitung permulaan dengan media puzzle. Kemampuan berhitung permulaan anak pada siklus I mencapai $40 \%$, pada siklus II meningkat mencapai $60 \%$ dan meningkat lebih baik lagi pada siklus III yaitu $80 \%$. Dengan demikian dapat disimpulkan bahwa variasi dalam pembelajaran memiliki peranan penting dalam meningkatkan kemampuan berhitung permulaan melalui media puzzle. Dengan demikian terbukti bahwa penerapan melalui media puzzle dapat meningkatkan kemampuan berhitung permulaan anak kelompok B di TK Permata Asi Serpong Kota Tangerang Selatan.
\end{abstract}

Kata Kunci : Berhitung Permulaan, Media Puzzle, Anak Usia 5-6 tahun

\section{Pengantar}

Pendidikan adalah bimbingan yang diberikan orang dewasa kepada anak yang belum dewasa untuk mencapai kedewasaannya. Pendidikan merupakan suatu proses pertumbuhan dan perkembangan, sebagai hasil interaksi individu dengan lingkungan sosial dan lingkungan fisik, berlangsung sepanjang hayat sejak manusia lahir. Hal ini senada dengan Paul Baltes (Santrock, 2002, h. 11) 


\section{Jurnal Program Studi Pendidikan Anak Usia Dini}

bahwa perkembangan adalah seumur hidup, multidimensional, multidireksional, plastis, melekat secara kesejarahan, multidisiplin, dan kontekstual. Dalam Undang-undang RI nomor 20 tahun 2003 tentang sistem pendidikan nasional, disebutkan bahwa pendidikan adalah usaha sadar untuk menyiapkan peserta didik melalui kegiatan bimbingan, pengajaran, dan/atau latihan bagi peranannya di masa yang akan datang

Tujuan dari pendidikan anak usia dini adalah membentuk anak Indonesia yang berkualitas, yaitu anak yang tumbuh dan berkembang sesuai dengan tingkat perkembangannya sehingga anak memiliki kesiapan yang optimal di dalam memasuki Pendidikan Dasar serta mengarungi kehidupan dimasa dewasannya. Salah satu kompetensi yang harus dimiliki oleh peserta didik TK adalah mampu mengikuti pendidikan selanjutnya dengan kesiapan yang optimal sesuai dengan tuntunan yang berkembang di masyarakat. Kemampuan dasar yang dikembangkan di TK meliputi kemampuan berbahasa, fisik/motorik, seni dan kemampuan kognitif. Pengembangan kemampuan kognitif bertujuan meningkatkan kemampuan berfikir anak. Pada kemampuan kognitif tersebut, anak diharapkan dapat mengenal konsep sains dan matematika sederhana. Perkembangan kemampuan matematika anak usia 5-6 tahun (Sujiono, dkk, 2009, h. 11.7) diharapkan membangun rasa keingintahuan anak secara alami tentang bentuk, ukuran, jumlah, dan konsep-konsep dasar dalam matematika.

Mempelajari matematika membutuhkan begitu banyak hafalan, hitungan atau melacak angka-angka. Keterampilan yang dibutuhkan adalah kemampuan untuk mengidentifikasi konsep-konsep matematika yang dapat dipelajari melalui kegiatan bermain. Kegiatan pembelajaran matematika pada anak diorganisir secara terpadu melalui tema-tema pembelajaran yang paling dekat dengan konteks kehidupan anak dan pengalaman-pengalaman riil. Guru dapat menggunakan media permainan dalam pembelajaran yang memungkinkan anak bekerja dan belajar secara individual, kelompok dan juga klasikal. Penggunaan media pada kegiatan pembelajaran matematika anak usia dini, khususnya dalam 
"Ceria"

\section{Jurnal Program Studi Pendidikan Anak Usia Dini}

pengenalan konsep bilangan bertujuan mengembangkan pemahaman anak terhadap bilangan dan operasi bilangan pada benda-benda kongkrit sebagai pondasi yang kokoh pada anak untuk mengembangkan kemampuan matematika pada tahap selanjutnya.

TK Permata Asri kelompok B sebagian besar anak belum mampu mengenal lambang bilangan. Pada usia ini seharusnya anak sudah bisa mengenal lambang bilangan dan memahaminya. Demikian pula dengan kemampuan berhitung permulaan dan menulis angka, kemampuan anak masih sangat minim. Dalam menulis angka anak masih sering salah dalam membedakan angka-angka yang hampir sama, seperti angka 2 dengan angka 5, dan angka 6 dengan angka 9 maupun sebaliknya. Selain itu juga kurangnya media pembelajaran dalam permainan berhitung permulaan yang tepat, hal ini lebih disebabkan oleh minimnya ruangan kelas yang dimiliki oleh TK Permata Asri, sehingga guru merasa kesulitan mencari tempat jika menambahkan media atau sumber belajar.

Sebagai indikator rendahnya kemampuan anak di TK Permata Asri, dapat dilihat dari 10 anak kelompok B masih belum mengenal angka. Berdasarkan permasalahan tersebut diatas, penulis tertarik untuk meneliti secara langsung pemanfaatan media puzzle sebagai salah satu cara meningkatkan konsep bilangan dan dapat memperbaiki kondisi pembelajaran di TK Permata Asri.

Salah satu kemampuan yang sangat penting bagi anak yang perlu dikembangkan dalam rangka membekali mereka, untuk bekal kehidupannya di masa depan dan saat ini adalah memberikan bekal kemampuan berhitung. Menurut Munandar (Susanto, 2011, h. 97) bahwa kemampuan merupakan daya untuk melakukan suatu tindakan sebagai hasil dari pembawaan dan latihan. Seseorang dapat melakukan sesuatu karena adanya kemampuan yang dimilikinya. Dalam pandangan Munandar, kemampuan ini ialah potensi seseorang yang merupakan bawaan sejak lahir mampu melakukan sesuatu. 
"Ceria"

\section{Jurnal Program Studi Pendidikan Anak Usia Dini}

Senada dengan Pakar sebelumnya, Robin (Susanto, 2011, h. 97), menyatakan kemampuan merupakan suatu kapasitas berbagai tugas dalam suatu pekerjaan tertentu. Kemampuan merupakan hal yang sangat penting untuk dikembangkan, dengan kemampuan anak dapat melakukan tindakan apapun termasuk mengenal lambang bilangan dalam berhitung permulaan. Menurut Susanto (2011, h. 98), Kemampuan merupakan suatu fase dalam perkembangan anak. Kemampuan anak prasekolah dalam fase-fase perkembangannya perlu diimbangi oleh berbagai faktor, yaitu intern dan ekstern anak.

Dengan demikian, dapat disimpulkan bahwa kemampuan merupakan suatu daya atau kesanggupan dalam diri setiap individu dimana daya ini dihasilkan dari pembawaan dan juga latihan yang mendukung individu dalam menyelesaikan tugasnya.

Menurut Susanto (2011, h. 98) Berhitung merupakan dasar dari beberapa ilmu yang dipakai dalam setiap kehidupan manusia. Dalam setiap aktivitasnya manusia tidak dapat terlepas dari peran matematika didalamnya, mulai dari penambahan, pengurangan, pembagian, sampai perkalian yang kesemuanya itu tidak dapat dilepaskan dalam kehidupan manusia sehari-hari.

Matematika merupakan ilmu yang sangat mendasar. Setiap kehidupan manusia bersentuhan dengan matematika, mulai saat menghitung kancing baju, hingga transaksi bisnis miliaran rupiah. Menurut Suriasumantri, (Susanto, 2011, h. 98) mengungkapkan bahwa matematika pada hakikatnya merupakan cara belajar untuk mengatur jalan pikiran seseorang dengan maksud melalui matematika ini seseorang akan dapat mengatur jalan pikirannya. Dengan menguasai matematika dan berbagai teorinya, maka dimungkinkan seseorang dapat lebih sistematis dalam me-manage jalan pikirannya. Hal ini senada dengan Betty (Hariwijaya dkk, 2013 h. 184) yang menyatakan anak-anak benar-benar akan belajar lebih baik jika santai dan sambil lalu. 
"Ceria"

\section{Jurnal Program Studi Pendidikan Anak Usia Dini}

Berdasarkan uraian diatas, dapat disimpulkan bahwa pengertian kemampuan berhitung permulaan merupakan kemampuan dasar yang dimiliki oleh setiap anak dalam hal mengembangkan kemampuan membilang lambang bilangan, mengenal berbagai macam bilangan, mencocokkan bilangan, membedakan 2 kumpulan benda, dan menyusun kepingan puzzle angka menjadi angka yang sempurna, sejalan dengan perkembangan kemampuannya dapat meningkatkan ke tahap pengertian mengenai hitungan. Kemampuan perkembangannya dimulai dari lingkungan yang terdekat dengan dirinya.

Anak dilahirkan sebagai makhluk yang memiliki kecerdasan. Akan tetapi banyak faktor yang mempengaruhi potensi kecerdasan anak. Faktor yang mempengaruhi kemampuan kecerdasan anak menurut (Sujiono, 2012, h.180-183). Sebagai berikut : a). Faktor hereditas (heredity factor) merupakan suatu kemampuan awal yang dimiliki oleh setiap individu yang baru dilahirkan untuk beradaptasi dengan lingkungannya. b) Faktor lingkungan faktor ini disebut dengan istilah nurture. c) Faktor umum merupakan faktor campuran dari faktor hereditas dan faktor lingkungan.

Ketiga faktor diatas akan mempengaruhi kecerdasan dan intelegensi anak usia dini dengan dominasi yang berbeda. Pada dasarnya anak memiliki kecerdasan secara alami, kecerdasan tersebut akan berkembang dengan baik jika potensi anak dikembangkan melalui stimulus dan upaya - upaya dari lingkungannya, karena lingkungan mempunyai pengaruh yang sangat besar.

Menurut Heinich, dkk (Anitah,dkk, 2014, h. 6.3). media merupakan alat saluran komunikasi. Media berasal dari bahasa Latin dan merupakan bentuk jamak dari kata "medium" yang secara harfiah berarti "perantara", yaitu perantara sumber pesan (a source) dengan penerima pesan (a receiver).

Menurut Djamarah dkk (1995, h. 120), media adalah alat bantu apa saja yang dapat dijadikan sebagai penyalur pesan guna mencapai tujuan pengajaran. Media sebagai alat bantu dalam proses mengajar adalah suatu kenyataan yang tidak dapat dipungkiri. Menurut Gagne (Sujiono,dkk, 2009, h. 8.4), media adalah 
"Ceria"

\section{Jurnal Program Studi Pendidikan Anak Usia Dini}

berbagai jenus komponen dalam lingkungan anak yang dapat mendorong anak untuk belajar.

Dari pemaparan diatas dapat disimpulkan bahwa media adalah alat bantu guru dalam proses belajar mengajar untuk menyampaikan pembelajaran yang sukar menjadi semakin asik dan menyenangkan.

Menurut Rokhmat Puzzle adalah permainan konstruksi melalui kegiatan memasang atau menjodohkan kotak-kotak, atau bangun-bangun tertentu sehingga akhirnya membentuk sebuah pola tertentu (http://ejournal.unp.ac.id/index.php/jupekhu). Menurut Nurfalah, dkk (2007, h. 114), puzzle adalah pemainan bongkar pasang. Permainan bongkar pasang atau puzzle dapat merangsang kerja otak anak saat menyusun kembali potonganpotongan puzzle yang telah diacak menjadi bentuk yang sempurna seperti semula. Sedangkan Menurut Suyadi (2015, h. 155) Puzzle transendental adalah puzzle yang dilukis secara khusus dengan lukisan yang diambil dari obyek yang dapat merangsang anak. Permainan puzzle ini sama dengan puzzle yang lain, tetapi puzzle ini dikhususkan dan dirancang untuk menstimulasi anak agar mengalami pengalaman batin. Jumlah potongan puzzle ini disesuaikan dengan usia anak.

Berdasarkan pendapat diatas dapat disimpulkan bahwa puzzle adalah permainan yang terdiri dari potongan gambar-gambar, kotak-kotak, huruf-huruf atau angka-angka yang disusun seperti dalam sebuah permainan yang akhirnya membentuk sebuah pola tertentu sehingga membuat peserta didik menjadi termotivasi untuk menyelesaikan puzzle secara cepat dan tepat.

\section{Metode}

Dalam penelitian ini peneliti menggunakan metode yang akan digunakan adalah metode penelitian kuantitatif dan kualitatif. Dalam penelitian ini peneliti menggunkan metode penelitian tindakan kelas (PTK). Dalam bahasa Inggris, method berarti cara. Apabila dikaitkan dengan pembelajaran, metode adalah cara 
"Ceria"

\section{Jurnal Program Studi Pendidikan Anak Usia Dini}

yang digunakan dalam membelajarkan anak. Menurut Sujiono, dkk (2009, h. 7.3), metode merupakan bagian dari strategi pembelajaran untuk mencapai tujuan.

Pada dasarnya Penelitian Tindakan Kelas sangat khas, yaitu ditandai dengan adanya siklus-siklus. Tahapan penelitian yang dilakukan dalam penelitian tindakan kelas ini yaitu perencanaan (planning), pelaksanaan tindakan (action), pengamatan (observation), dan refleksi (reflection).Hal ini sesuai dengan model yang dikembangkan oleh Kemmis dan Taggart dalam Kusumah dkk (2012, h. 20).

Kehadiran peneliti di TK Permata Asri, dilapangan pada saat penelitian sangat mutlak diperlukan, karena peneliti bertindak langsung mengamati penelitian dan menjadi pengumpuldata dan pelapor dari hasil penelitian.

Dalam penelitian ini peneliti melakukan penelitian di TK Permata Asri Kecamatan Serpong Kota Tangerang Selatan. Peneliti melakukan penelitian tindakan kelas ada kelopmpok B yang berjumlah 10 anak. Peneliti melakukan penelitian sejak bulan November 2105 sampai dengan bulan September 2016.

Instrumen penelitian adalah suatu alat yang dapat digunakan untuk memperoleh, mengolah dan menginterpretasikan informasi yang diperoleh dari para responden yang dilakukan dengan menggunakan pola ukur yang sama.

Instrumen adalah alat pada waktu penelitian digunakan untuk mengumpulkan data mengenai kemampuan berhitung permulaan usia 5-6 tahun di TK Permata Asri. Penelitian ini dikatakan berhasil apabila melalui media puzzle dapat meningkatkan kemampuan berhitung.

Salah satu masalah yang berhubungan dengan semua jenis penelitian adalah validitas. Artinya, apakah penelitian memang telah dilaksanakan seperti seharusnya dan hasil yang diperoleh dapat dipercaya, tanpa adanya analisis statistik? Penelitian tindakan memang tidak mengharap adanya jawaban akhir untuk pertanyaan atau masalah, tetapi menginginkan adanya peningkatan (dan perubahan) pada praktik pengajaran melalui pengembangan praktisi/guru. Uji validasi yang peneliti gunakan adalah validasi internal. Menurut Siregar (2014, h. 
"Ceria"

Jurnal Program Studi Pendidikan Anak Usia Dini

216) validitas internal dapat dilakukan dengan berbagai macam cara antara lain dengan melakukan perpanjangan pengamatan, peningkatan ketekunan dalam penelitian, triangulasi, diskusi dengan teman sejawat, analisis kasus negatif dam member check.

\section{Hasil dan Pembahasan}

Penelitian ini dilaksanakan di TK Permata Asri, Jl. Cemara Raya Blok RF 3 No. 6 Sektor 1-1 BSD Serpong Kota Tangerang Selatan. TK Permata Asri ini memiliki 3 kelas yaitu kelompok A, B, dan Kelompok Bermain. Subyek penelitian adalah kelompok B yang berusia 5-6 tahun dengan jumlah anak 10 orang siswa yang terdiri dari 7 perempuan dan 3 laki-laki. Pada kelompok B perlu ditingkatkan kemampuan berhitungnya karena pada usia 5-6 tahun, seharusnya sudah berkembang dengan baik, seperti halnya dalam mengenal lambang bilangan.

Penelitian tindakan kelas kelompok B di TK Permata Asri, BSD Serpong Kota Tangerang Selatan untuk mengembangkan kemampuan berhitung permulaan pada anak usia 5-6 tahun melalui permainan media puzzle angka dilaksanakan dalam 3 siklus.

Sebelum melaksanakan siklus-siklus, peneliti melaksanakan analisis pencarian fakta dengan melakukan observasi awal atau pra siklus. Dari data observasi yang dilakukan peneliti melalui permainan puzzle angka, ternyata kemampuan berhitung permulaan anak masih rendah. Hal ini yang menyebabkan anak belum mampu membilang angka (berhitung) dengan baik dan benar. Anak masih menunjukkan sikap bahwa kemampuan berhitung permulaan masih terlalu sulit. Dan anak masih belum mampu mengenal lambang bilangan dengan baik.

Perkembangan kemampuan berhitung permulaan pada anak dapat dilihat, bila anak mampu membilang atau mengurutkan angka (berhitung) dengan jelas, tepat dan benar, maka anak bisa dibilang mampu berhitung 
"Ceria"

Jurnal Program Studi Pendidikan Anak Usia Dini

permulaan dengan jelas, tepat dan benar. Tetapi bila anak belum mampu melakukan hal tersebut, maka anak disebut belum mampu berhitung permulaan dengan jelas, tepat, dan benar.

Tabel 1.1

Observasi Kondisi Awal Kemampuan Berhitung Permulaan

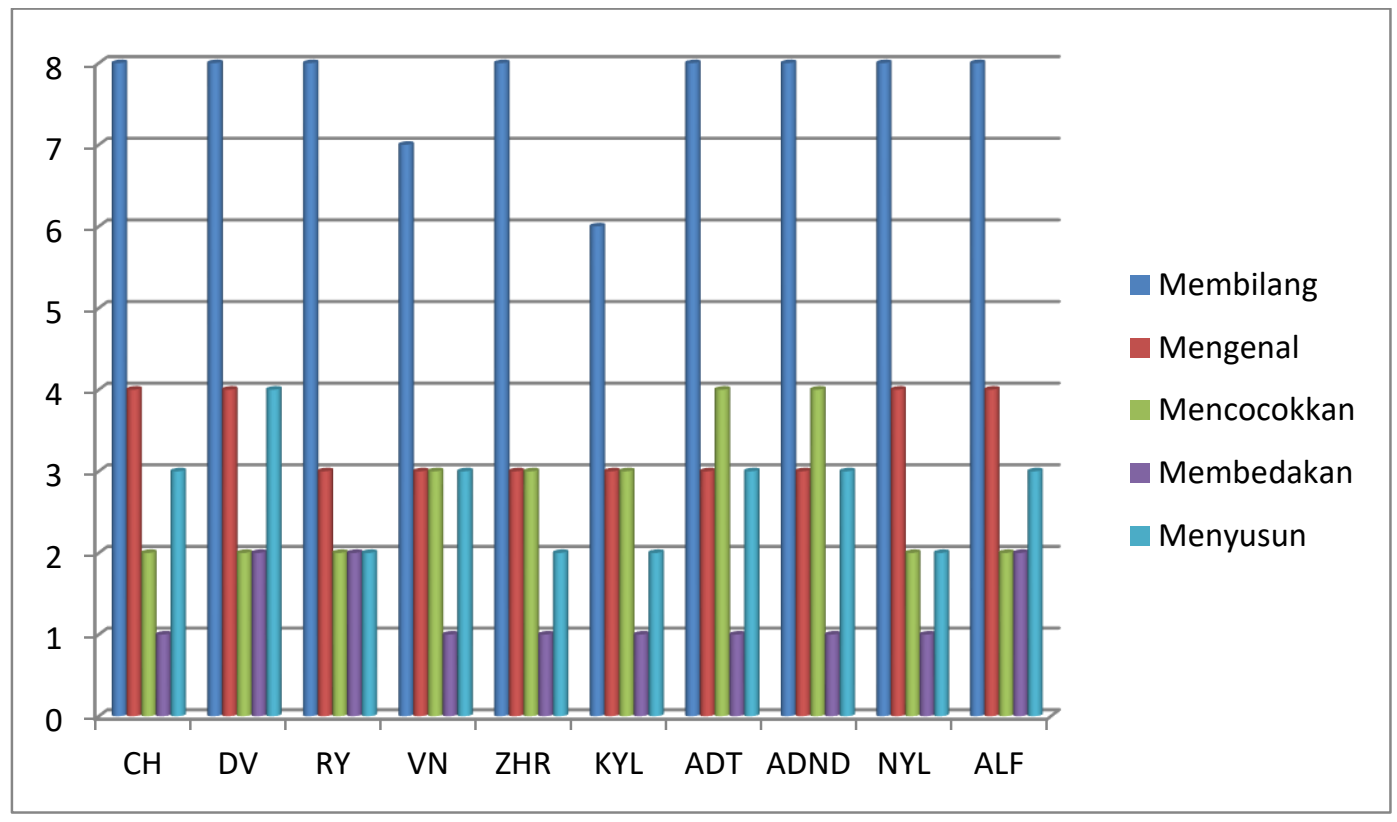

Berdasarkan hasil pengamatan yang dilakukan pada kondisi awal dari 10 orang anak di TK Permata Asri (Kel B) dinyatakan hampir secara keseluruhan dalam tahap Belum Berkembang. Sehingga perkembangan kemampuan berhitung permulaan anak pada kondisi awal masih belum ada peningkatan. Maka langkah selanjutnya yang akan dilakukan oleh peneliti agar perkembangan kemampuan berhitung permulaan anak dapat meningkat adalah dengan menggunakan media permainan dengan puzzle angka. Peneliti mencoba dengan upaya perbaikan menngunakan media puzzle angka dengan Penelitian Tindakan Kelas (PTK).

Berdasarkan pada permasalahan yang dihadapi oleh anak dalam perkembangan kemampuan berhitung permulaan berbagai penyebab munculnya permasalahan, sebagaimana telah diuraikan pada bagian pendahuluan, dilakukan serangkaian tindakan untuk mengatasi permasalahan 
"Ceria"

\section{Jurnal Program Studi Pendidikan Anak Usia Dini}

tersebut. Tindakan penelitian ini terdiri dari tiga siklus, dengan prosedur penelitian: penyusunan rencana tindakan, pelaksanaan, pengamatan atau observasi, dan refleksi.

Kemampuan berhitung permulaan anak usia 5-6 tahun di TK Permata Asri terlihat terjadi peningkatan yang sangat signifkan dari kondisi awal hingga sampai siklus III, yaitu dari 10 orang anak ada 8 orang anak yang Berkembang Sangat Baik. Pada tindakan siklui I peningkatan sebanyak $40 \%$, Siklus II $60 \%$, dan siklus III peningkatan menjadi $80 \%$. Refleksi proses pembelajaran yang dilakukan oleh peneliti pada ketiga siklus ini menunjukkan hasil yang lebih baik.

Penggunaan media puzzle dalam kegiatan pembelajara pada anak usia 56 tahun di TK Permata Asri dapat meningkatkan kemampuan berhitung permulaan. Peningkatan terjadi dalam penelitian yang dilakukan peneliti dalam 3 siklus. Siklus I mengalami peningkatan 40\%, sedangkan pada siklus 2 mengalami peningkatan $60 \%$ dan pada siklus 3 mengalami peningkatan yang signifikan yaitu $80 \%$. Peningkatan tersebut sesuai dengan indikator pencapaian yaitu $75 \%$.

Berdasarkan hasil siklus 1 menunjukkan adanya peningkatan berhitung permulaan. Hal ini terbukti dari perbandingan antara kondisi awal dan siklus 1 . Dari data terlihat bahwa pada kondisi awal belum adanya peningkatan namun setelah diberikan tindakan pada siklus 1 ada perubahan yang mencapai indikator meningkat 4 orang. Refleksi proses pembelajaran yang dilakukan oleh peneliti pada siklus ini menunjukkan hasil yang lebih baik.

Diterangkan bahwa secara keseluruhan anak belum mencapai indikator keberhasilan yang ditentukan sehingga perlu dilakukan perbaikan disiklus II. 
Tabel 1.2

Hasil Siklus I Kemampuan Berhitung Permulaan

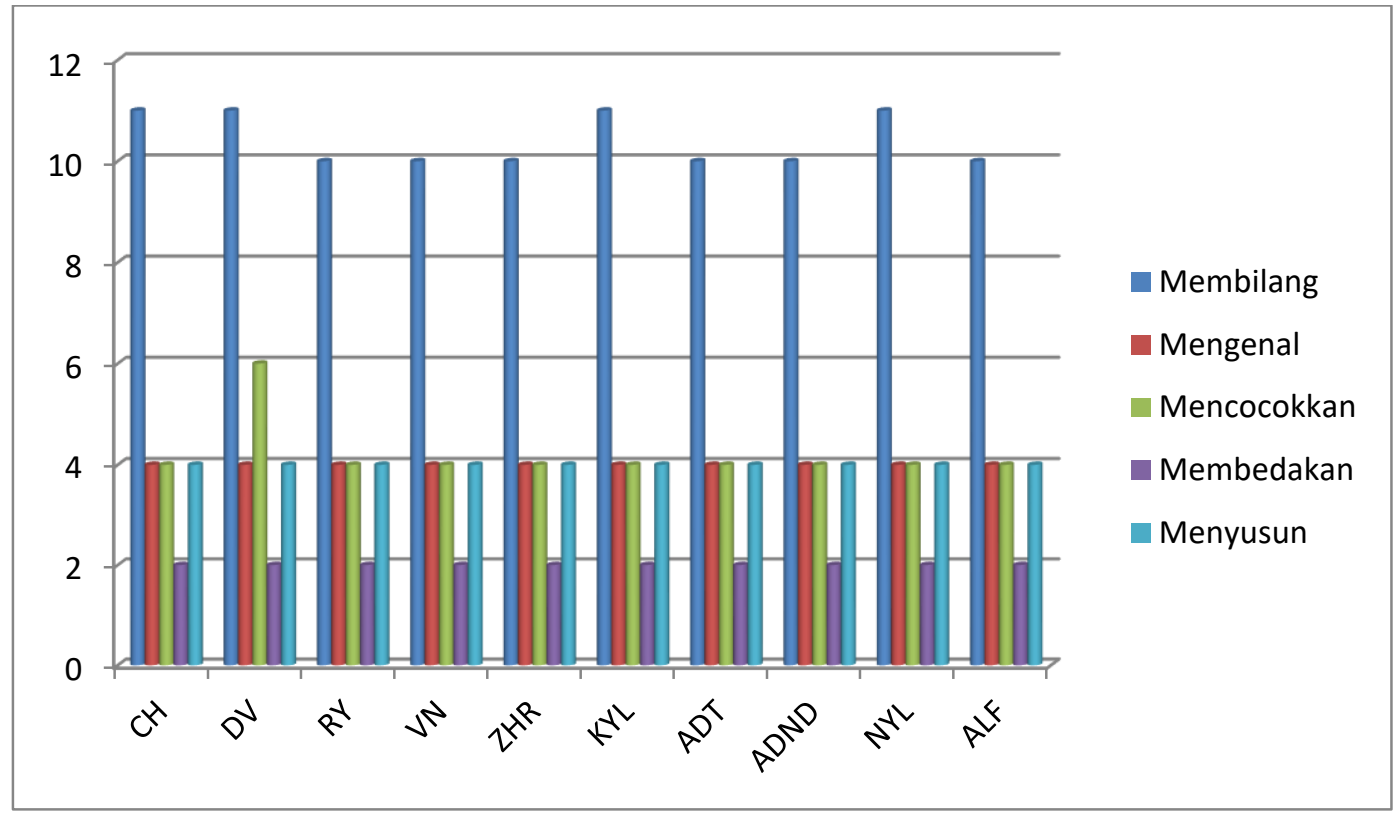

Berdasarkan hasil siklus II menunjukkan adanya peningkatan berhitung permulaan. Hal ini terbukti dari perbandingan antara siklus I dan siklus II. Dari data terlihat bahwa sebelum diberikan tindakan jumlah anak yang didapat mencapai indicator hanya 4 orang anak, sedangkan data setelah diberikan tindakan naik jadi 6 anak dari 10 Orang anak. Ini menggambarkan bahwa ada kenaikan sekitar $60 \%$ dari siklus I. Refleksi proses pembelajaran yang dilakukan oleh peneliti pada siklus ini menunjukkan hasil yang lebih baik.

Dari hasil di atas dapat diperoleh prosentase siklus II sebesar $60 \%$, diterangkan bahwa secara keseluruhan anak belum dapat mencapai indicator keberhasilan yang ditentukan sehingga perlu dilakuakn perbaikan di siklus III. 
Tabel 1.3

Observasi Siklus II Kemampuan Berhitung Permulaan

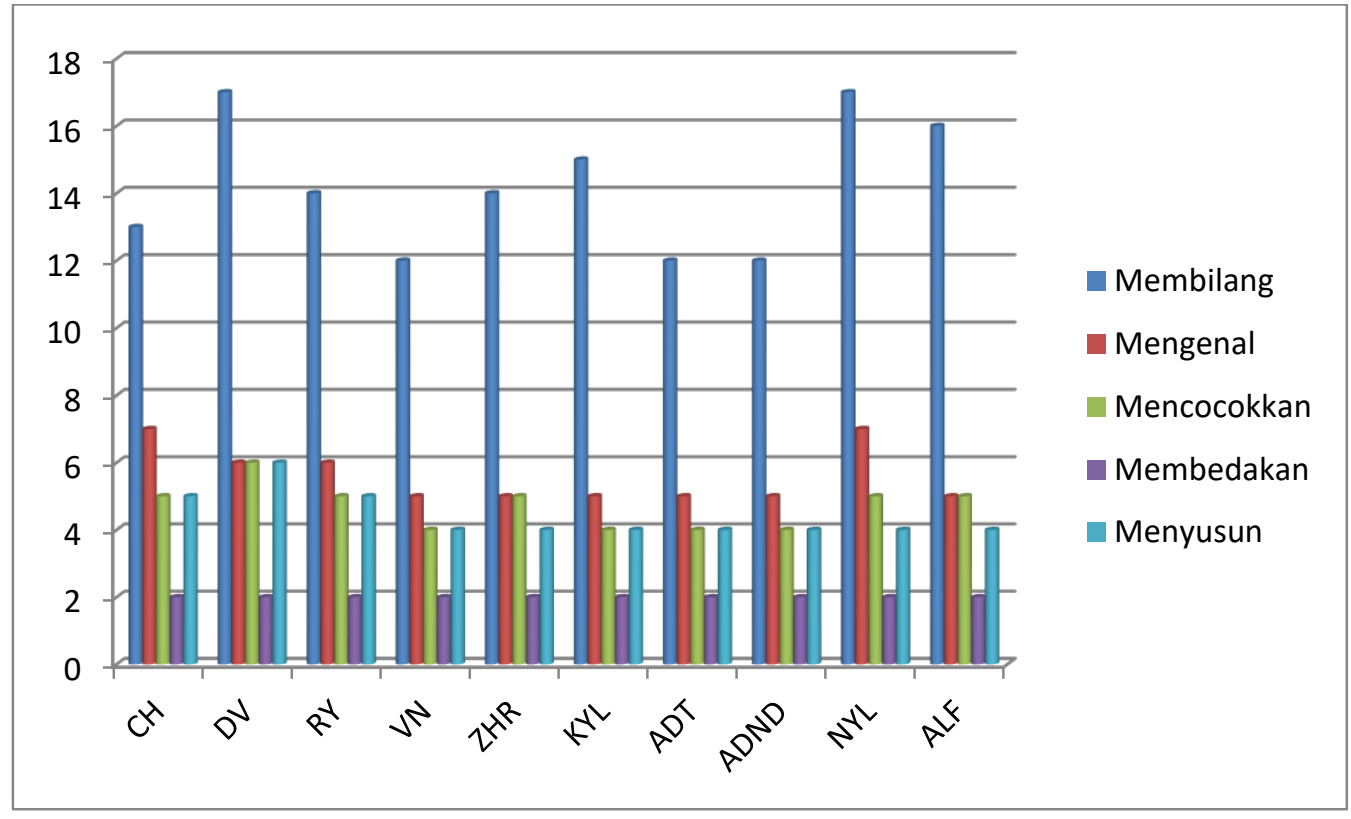

Berdasarkan pelaksanaan kegiatan pembelajaran pada siklus II maka pada siklus III pelaksanaan pembelajaran sudah berjalan dengan baik, ini dapat dilihat pada data dari 10 orang anak hanya 2 orang anak yang belum mencapai indicator yang ditetapkan. Hal ini dapat dilihat dari persentase perbandingan antara siklus I dan II yaitu 50 \% dan pada siklus II dan III menjadi $80 \%$.

Dari hasil tindakan dan kolaborator memutuskan bahwa peneliti berhenti disiklus III, karena perkembangan berhitung permulaan anak sudah meningkat secara signifikan mulai dari kondisi awal belum sama sekali ada peningkatan, siklus I menjadi $40 \%$, siklus II meningkat menjadi $60 \%$, dan siklus III meningkat menjadi $80 \%$. Dari hasil observasi diketahui bahwa perkembangan berhitung permulaan anak usia 5-6 Tahun di TK Permata Asri dapat ditingkatkan melalui pembelajaran berhitung permulaan dengan menggunakan media puzzle angka.

Tingkat keberhasilan pelaksanaan siklus I adalah $40 \%$ anak sudah mulai aktif mengikuti kegiatan membilang dengan lambang bilangan, pada siklus II anak berhasil $60 \%$, sedangkan pada siklus III anak berhasil $80 \%$, jika ketiga 
"Ceria"

Jurnal Program Studi Pendidikan Anak Usia Dini

siklus tadi dibandingkan maka siklus II lebih berhasil dari siklus I dan siklus III berhasil dari siklus II.

Kemampuan berhitung permulaan anak usia 5-6 tahun di TK Permata Asri terlihat terjadi peningkatan yang sangat signifkan dari kondisi awal hingga sampai siklus III, yaitu dari 10 orang anak ada 8 orang anak yang Berkembang Sangat Baik. Pada tindakan siklus I peningkatan sebanyak 40\%, Siklus II 60\%, dan siklus III peningkatan menjadi $80 \%$. Refleksi proses pembelajaran yang dilakukan oleh peneliti pada ketiga siklus ini menunjukkan hasil yang lebih baik.

Tabel 1.3

Hasil Siklus III Kemampuan Berhitung Permulaan

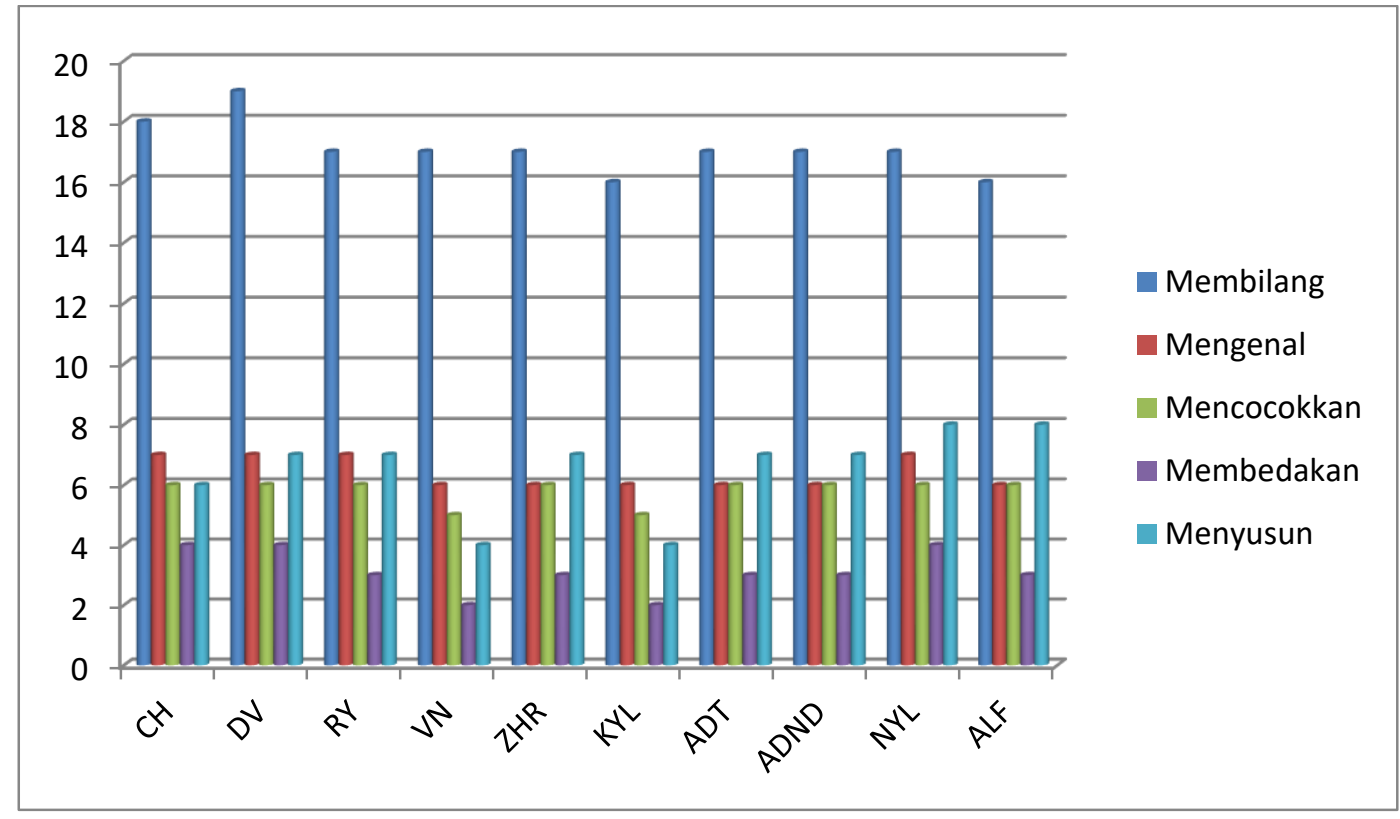

Kegiatan Pembelajaran Media Puzzle di TK Permata Asri dalam Meningkatkan Kemampuan Berhitung Permulaan Usia 5-6 tahun. Dari hasil penelitian diperoleh keterangan bahwa kegiatan pembelajaran media puzzle dilakukan dengan persiapan yang cukup matang. Melalui persiapan pembuatan rencana kegiatan harian (RKH). Peneliti juga mempersiapkan media puzzle yang menarik sesuai dengan instrumen penelitian agar anak-anak senang dan tertarik memainkannya. 
"Ceria"

Jurnal Program Studi Pendidikan Anak Usia Dini

Pada kegiatan bermain puzzle anak dapat merangkai atau menghubungkan potongan-potongan puzzle yang belum tersusun rapi menjadi bentuk yang utuh. Hal ini senada dengan Suyadi (2015 h. 155) permainan puzzle adalah merangkai potongan-potongan bergambar khusus yang dirancang untuk menstimulasi anak. Menurut Suriasumantri, (Susanto, 2011, h. 98) mengungkapkan bahwa matematika pada hakikatnya merupakan cara belajar untuk mengatur jalan pikiran seseorang dengan maksud melalui matematika ini seseorang akan dapat mengatur jalan pikirannya. Dengan menguasai matematika dan berbagai teorinya, maka dimungkinkan seseorang dapat lebih sistematis dalam me-manage jalan pikirannya. Bermain puzzle matematika dapat mengontrol konsentrasi tangan dan otak anak untuk menyusun puzzle matematika menjadi urutan bilangan yang utuh atau sempurna.

\section{Kesimpulan}

Kegiatan pembelajaran puzzle angka pada anak usia 5-6 tahun di TK Permata Asri, terjadi peningkatan kemampuan berhitung permulaan pada anak, ini terlihat dari penelitian awal dari 10 orang anak yang belum mampu mengenal konsep, membedakan lambang bilangan, setelah melakukan kegiatan bermain puzzle angka, kemampuan berhitung permulaan anak terjadi peningkatan yang signifikan dan dapat berkembang dengan baik.

Perkembangan kemampuan berhitung permulaan anak usia 5-6 tahun di TK Permata Asri setelah mendapat tindakan. Hal ini dibuktikan dengan adanya peningkatan, yakni dari siklus I 40\% dari 10 anak. Siklus II mengalami peningkatan sebesar $60 \%$ dari 10 anak. Dan pada siklus III mengalami peningkatan sebesar $80 \%$ dari 10 anak. Sehingga prosentase kenaikan dari siklus I ke siklus II adalah sebesar $20 \%$ dan prosentase kenaikan dari siklus II ke siklus III adalah $20 \%$.

Terbukti dari hipotesis perkembangan kemampuan berhitung permulaan pada anak usia 5-6 tahun dengan media puzzle setelah tindakan mengalami 
"Ceria"

\section{Jurnal Program Studi Pendidikan Anak Usia Dini}

peningkatan yang signifikan. Media pembelajaran perlu disiapkan dengan baik agar menumbuhkan minat anak untuk melaksanakan kegiatan.

Berdasarkan hasil penelitian yang disimpulkan di atas, dan berdasarkan pengalaman peneliti selama melaksanakan penelitian di TK Permata Asri, Serpong Kota Tangerang Selatan, peneliti memberikan saran untuk siswa dengan menggunakan media puzzle angka dapat meningkatkan kemampuan berhitung permulaan pada anak, caranya siswa difasilitasi berbagai media puzzle yang menarik serta siswa diberikan semangat dan dorongan saran untuk guru diharapkan media bermain puzzle angka diterapkan pada proses pembelajaran di Pendidikan Anak Usia Dini dengan cara ini guru lebih bisa berkreasi mengembangkan peningkatan perkembangan kemampuan berhitung permulaan anak. Guru juga harus menjadi model pada proses pembelajaran karena anak belajar dari model yang ditampilkan.

Saran untuk sekolah perlunya menyediakan media belajar sebagai penyampaian pesan-pesan pendidik untuk anak usia dini, caranya dengan menyediakan media belajar untuk dan sarana prasarana yang sesuai untuk anak usia dini, sehingga anak-anak mudah untuk menerima pembelajaran yang dilaksanakan. Saran untuk Orang Tua agar lebih memperhatikan setiap perkembangan dan potensi yang dimiliki anak. Dan memahami pentingnya kemampuan berhitung permulaan pada anak dengan memberikan pengajaran yang sesuai dengan suasana yang menyenangkan.

\section{Daftar Pustaka}

Anitah, S dkk (2014). Strategi Pembelajaran di SD. Tangerang Selatan:Universitas Terbuka.

Djamarah, S. B \& Zain, A (2006). Strategi Belajar Mengajar. Jakarta:Rineka Cipta.

Hariwijaya, M \& Sustiwi, A (2011). Multiple Intellegences Pendekatan Tematis Super Kreatif Bagi Anak Prasekolah. Yogyakarta:Mitra Media 
"Ceria"

Jurnal Program Studi Pendidikan Anak Usia Dini

Jamaris, Martin. DR (2003).Perkembangan dan Pengembangan Anak Usia Taman Kanak-kanak. Universitas Negeri Jakarta.

Kusumah, W \& Dwitagama, D (2012). Mengenal Penelitian Tindakan Kelas. Jakarta:Indeks.

Nurfalah, dkk (2007). Model Strategi Pembelajaran Kelompok Bermain melalui Metode Dongeng. Bandung. Jayagiri.

Siregar, Syofian (2014). Statistika Deskriptif untuk Penelitian. Jakarta: Rajawali Pers.

Sujiono, Y.N (2009). Metode Pengembangan Kognitif. Jakarta: Universitas Terbuka.

Sujiono, Y.N (2012). Konsep Dasar Pendidikan Anak Usia Dini. Jakarta: PT. Indeks.

Susanto, Ahmad. Drs (2011). Perkembangan Anak Usia Dini (Pengantar dalam berbagai Aspeknya). Jakarta: Prenada Media Group.

Suyadi, (2015). Cerdas dengan Spiritual Education Games. Yogyakarta. Serambi Semesta Distribusi

http://ejournal.unp.ac.id/index.php/jupekhu 